\title{
Therapeutic Value of Voltage-Gated Sodium Channel Inhibitors in Breast, Colorectal, and Prostate Cancer: A Systematic Review
}

\author{
Fabiola Martin ${ }^{1,2}$, Chiedu Ufodiama ${ }^{2}$, Ian Watt ${ }^{3}$, Martin Bland ${ }^{3}$ and \\ William J. Brackenbury ${ }^{*}$ * \\ ${ }^{1}$ Department of Biology, University of York, York, UK, ${ }^{2}$ Hull York Medical School, University of York, York, UK, ${ }^{3}$ Department \\ of Health Sciences, University of York, York, UK
}

\section{OPEN ACCESS}

Edited by:

Jean-Yves Le Guennec, Université de Montpellier, France

Reviewed by:

Sébastien Roger,

University of Tours, France

Ludovic Gillet,

Lausanne University Hospital,

Switzerland

${ }^{*}$ Correspondence:

William J. Brackenbury

william.brackenbury@york.ac.uk

Specialty section

This article was submitted to Pharmacology of Ion Channels

and Channelopathies,

a section of the journal

Frontiers in Pharmacology

Received: 05 October 2015

Accepted: 30 October 2015

Published: 12 November 2015

Citation:

Martin F, Ufodiama C, Watt I, Bland M and Brackenbury WJ (2015)

Therapeutic Value of Voltage-Gated Sodium Channel Inhibitors in Breast,

Colorectal, and Prostate Cancer:

A Systematic Review.

Front. Pharmacol. 6:273.

doi: 10.3389/fphar.2015.00273
Although survival rates of breast, colon, and prostate cancers are improving, deaths from these tumors frequently occur due to metastasis. Voltage-gated $\mathrm{Na}^{+}$channels (VGSCs) are membrane proteins, which regulate membrane current and cellular migration during nervous system organogenesis. VGSCs are also expressed in fibroblasts, immune cells, glia, and metastatic cancer cells. VGSCs regulate migration and invasion of breast, bowel, and prostate cancer cells, suggesting that they may be novel anti-metastatic targets. We conducted a systematic review of clinical and preclinical studies testing the effects of VGSC-inhibiting drugs in cancer. Two-hundred and four publications were identified, of which two human, two mouse, and 20 in vitro publications were included. In the clinical studies, the effect of these drugs on survival and metastatic relapse is not clear. The 22 preclinical studies collectively suggest that several VGSC-inhibiting drugs inhibit cancer proliferation, migration, and invasion. None of the human and only six of the preclinical studies directly investigated the effect of the drugs on VGSC activity. Studies were difficult to compare due to lack of standardized methodology and outcome measures. We conclude that the benefits of VGSC inhibitors require further investigation. Standardization of future studies and outcome measures should enable meaningful study comparisons.

Keywords: anticonvulsants, breast neoplasms, colonic neoplasms, prostatic neoplasms, sodium channels

\section{INTRODUCTION}

Cancers of the breast, colon, and prostate collectively account for the majority of cancer diagnoses in adults in the Western world (Jemal et al., 2011). Although survival rates are improving, deaths from these cancers frequently occur due to metastasis. Metastasis is a complex process, which involves detachment of cancer cells from the primary site, local invasion into surrounding tissues and dissemination to distant sites in other tissues. Metastatic disease is invariably incurable, and the molecular mechanisms underlying metastasis are not yet fully understood. Thus, there is an urgent need to develop new molecularly targeted anti-metastatic therapies with curative intent. 
Voltage-gated $\mathrm{Na}^{+}$channels (VGSCs) are heteromeric membrane protein complexes made up of a single poreforming $\alpha$ subunit $\left(\mathrm{Na}_{\mathrm{v}} 1.1-\mathrm{Na}_{\mathrm{v}} 1.9\right)$ and one or more smaller auxiliary $\beta$ subunits $(\beta 1-\beta 4$; Catterall, 2000$)$. The $\beta$ subunits contain an extracellular immunoglobulin loop and do not form part of the ion-conducting pore. Instead, they modulate channel gating and function as cell adhesion molecules (Brackenbury and Isom, 2011). The influx of $\mathrm{Na}^{+}$ions through VGSCs is responsible for the membrane depolarization phase underlying action potentials in electrically excitable neurons and muscle cells. VGSC $\alpha$ and $\beta$ subunits have also been shown to regulate several key aspects of organogenesis in the developing central nervous system, including cell proliferation, neurite outgrowth, neuronal pathfinding, and migration (Brackenbury et al., 2008a, 2010, 2013). Abnormal function of VGSCs contributes to various excitability-related pathologies, including epilepsy, cardiac arrhythmia, and neuropathic pain. As a result, a number of drugs have been developed to target VGSCs (Mantegazza et al., 2010).

Voltage-gated $\mathrm{Na}^{+}$channels are also expressed in cells that are traditionally considered to be "non-excitable", including fibroblasts, immune cells, glia, and metastatic cancer cells (Black and Waxman, 2013). In metastatic cancer cells, including those of the breast, bowel, and prostate, VGSCs have been shown to potentiate a number of cellular behaviors associated with metastasis, including migration and invasion (Brackenbury et al., 2008b; Brackenbury, 2012; Besson et al., 2015). Furthermore, emerging preclinical data suggest that pharmacologically targeting VGSCs may reduce local invasion and metastasis in mouse models (Driffort et al., 2014; Nelson et al., 2015). The potential utility of VGSC-inhibiting agents as anti-metastatic therapies has not surfaced in the clinic. However, the preclinical data raise the intriguing possibility that cancer patients taking VGSC-inhibiting medication for other pre-existing indications, e.g., epilepsy, may have improved cancer-specific outcome compared with those not taking such medications (Fairhurst et al., 2014).

Although a number of recent reviews have explored the literature relating to the contribution of VGSCs to metastasis (Roger et al., 2006; Brackenbury and Isom, 2008; Brackenbury et al., 2008b; Brackenbury, 2012; Fraser et al., 2014a; Besson et al., 2015), there has been no systematic review assessing the evidence for the potential therapeutic use of VGSC-inhibiting agents in cancer. We therefore set out to conduct a systematic review of the current clinical and preclinical studies that have been performed using known VGSC-inhibiting drugs in cancer cells. We have focused the review on cancers of the breast, bowel, and prostate because VGSC expression has been most extensively characterized in these tumors (Brackenbury, 2012). We have identified two clinical studies that explored the effect of VGSC inhibitors on clinical characteristics in cancer patients. However, the effect of these drugs on survival and metastatic relapse is not clear. Nonetheless, our search uncovered 22 preclinical studies collectively suggesting that several VGSC-inhibiting drugs inhibit various aspects of the hallmarks of cancer, including proliferation, angiogenesis, and invasion.

\section{MATERIALS AND METHODS}

\section{Search Strategy}

A systematic literature search was performed to identify studies using VGSC-inhibiting drugs as part of the treatment of patients with colorectal, breast, and prostate cancer. The databases searched were Medline and Embase (Ovid interface) from inception until May 20th, 2015. Controlled vocabulary and free text terms were used in these search strategies. The search terms used were "[Sodium Channel blocking drugs] AND [colorectal cancer or breast cancer or prostate cancer]". VGSC-inhibiting drugs included in the search are in Table 1. No limits or methodological filters were applied to these searches in order to avoid bias. The full search strategies are listed in Supplementary Tables S1 and S2. The protocol for the search strategy was registered with PROSPERO (registration number CRD42014013574).

\section{Selection}

The PRISMA guidelines were used as a basis for the selection (Moher et al., 2009). Bibliographic details and their respective abstracts were downloaded into EndNote. Studies were then selected through a four-step process (Figure 1). The initial step was the identification of the studies from EMBASE and MEDLINE. This was achieved by reviewing the title of each study. The second step of the process involved identifying and removing any duplicates, removing of conference abstracts and obvious false selections. The third step selected

\section{TABLE 1 | Drug search terms used in systematic review.}

Carbamazepine

Carbamazepine derivatives and other carboxamides

Class Ib anti-arrhythmic agents

Disopyramide

Eslicarbazepine acetate

Flecainide

Lacosamide

Lamotrigine

Lidocaine

Mexiletine

Moricizine

Oxcarbazepine

Phenytoin

Procainamide

Propafenone

Quinidine

Ranolazine

Riluzole

Rufinamide

Sodium channel blocking drugs

Sodium valproate

Tocainide

Topiramate

Valproic acid 


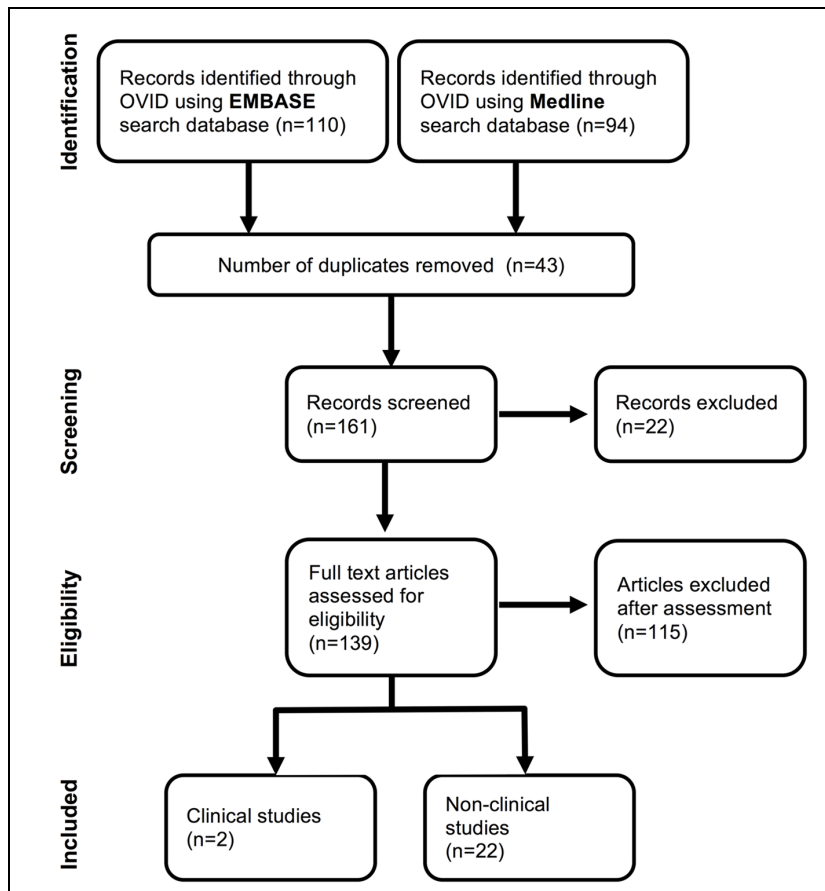

FIGURE 1 | Flow chart illustrating selection of studies for systematic review. Initial exclusions were made following assessment of abstracts. Further studies were excluded after full text assessment due to language restrictions or study not looking at the effects of a voltage-gated $\mathrm{Na}^{+}$ channels (VGSC)-inhibiting drug listed in Table 1. The final shortlist of studies was achieved by scoring study quality and evidence against the standardized pre-piloted criteria in Supplementary Table S3. A minimum score of 3/5 was required for inclusion.

manuscripts by the following inclusion criteria: the VGSCinhibiting drug that was used, cancer was of the breast and/or colorectum and/or prostate, participants were over the age of 18 years. The exclusion criteria were: non-English abstract, study not peer-reviewed. At this stage, the full text was reviewed.

In the fourth step of the selection process, we modified a standardized Quality Assessment Tool for Observational Cohort and Cross-Sectional Studies (mQATSO) to quantify study quality and evidence (Supplementary Table S3; NHLBI, 2014). The following criteria each received a score of one: human studies $=1$, using at least one VGSC-inhibitor $=1$, at least one of the index cancers $=1$, measuring cancer survival, and/or metastasis outcome $=1$, specifically investigating the VGSCinhibiting mode of action of the $\operatorname{drug}(\mathrm{s})=1$. Thus, a maximum score of 5 could be achieved. All data were collected in a spreadsheet in Microsoft Excel. Three reviewers (FM, CU, and WB) screened studies independently and then discussed and resolved discrepancies together.

\section{RESULTS}

Using search terms detailed in the section "Materials and Methods", 204 items were identified in EMBASE and Medline, 43 of which were duplicates and were removed. Abstract screening excluded 22 additional records for not meeting inclusion criteria. Full manuscript screening contained 139 items, and 115 were excluded scoring $<3 / 5$ on quality assessment (Figure 1). Two human and 22 preclinical in vivo and in vitro publications were included in the final study.

The two human studies investigated a VGSC inhibitor in one of the cancers of interest and tested drug influence on cancer survival. However, neither of the studies tested specifically the VGSC-inhibiting activity of the intervention and therefore scored 4/5. Raderer et al. (1993) conducted an observational study of quinidine as a multi-drug resistance modifier adjuvant to pirarubicin in 14 women with metastatic and/or refractory breast cancer to test side-effects and survival outcomes, but an objective survival benefit was not observed. Wheler et al. (2014) conducted a phase 1 dose finding study of sodium valproate as adjunctive therapy to bevacizumab in 57 patients with cancer, 40 of whom had colon, breast, or prostate cancer. They attributed the survival benefits detected with sodium valproate to its histone deacetylase inhibition activity, which was dose independent (Table 2), (Wheler et al., 2014).

The remaining 22 papers scored between 3 and 4 out of five, and all of them were preclinical studies (Figure 2). Interestingly, four in vitro studies specifically tested the VGSCinhibiting mode of action of the interventions (Figure 2). Three studies investigated prostate cancer cell lines and detected inhibited cell growth at clinically relevant drug doses of riluzole, sodium valproate, carbamazepine, phenytoin, and its derivatives (Abdul and Hoosein, 2001, 2002; Anderson et al., 2003), and one study used breast cancer cell lines and detected reduced migration and cell invasion with phenytoin (Yang et al., 2012). In the first study, Abdul and Hoosein (2001) showed that carbamazepine and phenytoin both reduced secretion of prostate-specific antigen (PSA) and interleukin6 (IL-6) in prostate cancer cells. They found that valproate also inhibited PSA and IL-6 secretion to a lesser extent, although they attributed the effect of valproate to $\mathrm{Ca}^{2+}$ channel inhibition, rather than to its possible role as a VGSC inhibitor. All three drugs inhibited prostate cancer cell proliferation. In a subsequent study (Abdul and Hoosein, 2002), the same authors showed that riluzole also inhibited prostate cancer cell proliferation. However, in both studies, the authors did not directly show whether or not functional VGSCs were present in the tumor cells, e.g., by electrophysiological recording, nor did they provide evidence to indicate whether the drugs elicited their effects through VGSC inhibition or another, VGSC-independent mechanism. The third study (Anderson et al., 2003) showed that phenytoin and several other inhibitors (hydroxyamides and a hydantoin) reduced proliferation of an androgen-independent prostate cancer cell line, without significantly affecting viability. The authors also showed that the drugs inhibited $\mathrm{Na}^{+}$current (i.e., VGSC functional activity) in Xenopus oocytes expressing $\mathrm{Na}_{\mathrm{v}} 1.2$, although they did not show whether the drugs inhibited endogenous VGSC activity in the prostate cancer cells. In the fourth study (Yang et al., 2012), we reported that 
TABLE 2 | Summary of included studies.

\begin{tabular}{|c|c|c|c|c|c|}
\hline Reference & Population & Study design & Intervention & Outcome & Score $/ 5$ \\
\hline Raderer et al., 1993 & $\begin{array}{l}\text { Fourteen females } \\
\text { with advanced } \\
\text { refractory breast } \\
\text { cancer }\end{array}$ & $\begin{array}{l}\text { Phase } 1 / \text { II clinical trial of } \\
\text { quinidine and } \\
\text { pirarubicin }\end{array}$ & $\begin{array}{l}\text { Two-hundred and fifty } \\
\text { milligram quinidine } \\
\text { bisulphate twice daily } \\
\text { for } 5 \text { days. Cycle } \\
\text { repeated every } \\
\text { 3-4 weeks. }\end{array}$ & $\begin{array}{l}\text { Stable disease in } \\
\text { six patients, } \\
\text { progression in eight } \\
\text { patients }\end{array}$ & 4 \\
\hline Wheler et al., 2014 & $\begin{array}{l}\text { Fifty-seven patients } \\
\text { with colorectal } \\
(51 \%), \text { prostate } \\
(10 \%), \text { breast }(9 \%) \text {, } \\
\text { or other cancer } \\
(31 \%)\end{array}$ & $\begin{array}{l}\text { Phase I trial of } \\
\text { bevacizumab and VPA } \\
\text { in patients with } \\
\text { untreatable advanced } \\
\text { cancer }\end{array}$ & $\begin{array}{l}\text { Valproic acid } 5.3 \text { mg/kg } \\
\text { once } \\
\text { daily }+ \text { bevacizumab } \\
11 \mathrm{mg} / \mathrm{kg} \text { every } \\
14 \text { days }\end{array}$ & $\begin{array}{l}\text { Safe combination. } \\
\text { Improved overall } \\
\text { survival if } \\
\text { hypertension } \\
\text { present }\end{array}$ & 4 \\
\hline Abdul and Hoosein, 2001 & $\begin{array}{l}\text { LNCaP, PC-3 and } \\
\text { DU-145 prostate } \\
\text { cancer cell lines }\end{array}$ & $\begin{array}{l}\text { In vitro study of drug } \\
\text { effect on proliferation }\end{array}$ & $\begin{array}{l}\text { Phenytoin, } \\
\text { carbamazepine, } \\
\text { valproate }\end{array}$ & $\begin{array}{l}\text { Drugs inhibited } \\
\text { proliferation at } \\
\text { clinically relevant } \\
\text { doses }\end{array}$ & 4 \\
\hline Abdul and Hoosein, 2002 & $\begin{array}{l}\text { LNCaP, PC-3, } \\
\text { DU-145, and } \\
\text { MDA-PCA-2B } \\
\text { prostate cancer cell } \\
\text { lines }\end{array}$ & $\begin{array}{l}\text { In vitro study of drug } \\
\text { effect on proliferation }\end{array}$ & Riluzole & $\begin{array}{l}\text { Riluzole inhibited } \\
\text { proliferation }\end{array}$ & 4 \\
\hline Anderson et al., 2003 & PC-3 & $\begin{array}{l}\text { Compound discovery } \\
\text { of phenytoin analogs }\end{array}$ & Phenytoin and analogs & $\begin{array}{l}\text { Phenytoin and } \\
\text { synthesized } \\
\text { analogs inhibit } \\
\text { proliferation }\end{array}$ & 4 \\
\hline Driffort et al., 2014 & $\begin{array}{l}\text { Spontaneous } \\
\text { metastasis murine } \\
\text { model using } \\
\text { MDA-MB-231 } \\
\text { breast cancer cells }\end{array}$ & $\begin{array}{l}\text { In vivo study of drug } \\
\text { effect on lung } \\
\text { metastasis }\end{array}$ & Ranolazine & $\begin{array}{l}\text { Ranolazine inhibits } \\
\text { lung metastasis } \\
\text { in vivo and } \mathrm{Na}^{+} \\
\text {current, invasion } \\
\text { and extracellular } \\
\text { matrix degradation } \\
\text { in vitro }\end{array}$ & 4 \\
\hline Nelson et al., 2015 & $\begin{array}{l}\text { Orthotopic murine } \\
\text { breast cancer } \\
\text { model using } \\
\text { MDA-MB-231 } \\
\text { breast cancer cells }\end{array}$ & $\begin{array}{l}\text { In vivo study of drug } \\
\text { effect on breast tumor } \\
\text { growth, invasion, and } \\
\text { metastasis }\end{array}$ & $\begin{array}{l}\text { Phenytoin } 60 \text { mg/kg } \\
\text { once daily }\end{array}$ & $\begin{array}{l}\text { At clinically relevant } \\
\text { dose, phenytoin } \\
\text { reduces tumor } \\
\text { growth, } \\
\text { proliferation, } \\
\text { invasion, and } \\
\text { metastasis }\end{array}$ & 4 \\
\hline Yang et al., 2012 & $\begin{array}{l}\text { MCF-7 and } \\
\text { MDA-MB-231 } \\
\text { breast cancer cells }\end{array}$ & $\begin{array}{l}\text { In vitro study of drug } \\
\text { effect on } \mathrm{Na}^{+} \text {current, } \\
\text { migration, and invasion }\end{array}$ & Phenytoin & $\begin{array}{l}\text { Phenytoin inhibits } \\
\text { migration and } \\
\text { invasion of } \\
\text { VGSC-expressing } \\
\text { MDA-MB-231 cells }\end{array}$ & 4 \\
\hline Al Snafi et al., 2014 & $\begin{array}{l}\text { AMN-3 breast } \\
\text { cancer cells }\end{array}$ & $\begin{array}{l}\text { In vitro study of drug } \\
\text { effect on cell viability }\end{array}$ & Valproate & $\begin{array}{l}\text { Valproate inhibits } \\
\text { cell proliferation }\end{array}$ & 3 \\
\hline Angelucci et al., 2006 & $\begin{array}{l}\text { LNCaP, DU145, } \\
\text { PC-3 prostate } \\
\text { cancer cells }\end{array}$ & $\begin{array}{l}\text { In vitro study of drug } \\
\text { effect on growth and } \\
\text { apoptosis }\end{array}$ & $\begin{array}{l}\text { Valproic acid and } \\
\text { butyrate analogs }\end{array}$ & $\begin{array}{l}\text { Valproic acid } \\
\text { inhibits cell growth } \\
\text { and stimulates } \\
\text { programmed cell } \\
\text { death }\end{array}$ & 3 \\
\hline Chang et al., 2014 & $\begin{array}{l}\text { MCF-7 mammary } \\
\text { carcinoma and } \\
\text { MCF-10A epithelial } \\
\text { cells }\end{array}$ & $\begin{array}{l}\text { In vitro study of drug } \\
\text { effect on apoptosis }\end{array}$ & $\begin{array}{l}\text { Lidocaine, } \\
\text { tetracaine }\end{array}$ & $\begin{array}{l}\text { Drugs inhibited } \\
\text { morphological } \\
\text { changes but were } \\
\text { not pro-apoptotic }\end{array}$ & 3 \\
\hline Fortunati et al., 2008 & $\begin{array}{l}\text { MCF-7, ZR-75-1, } \\
\text { MDA-MB-231, and } \\
\text { MDA-MB-435 } \\
\text { breast cancer cells }\end{array}$ & $\begin{array}{l}\text { In vitro study of drug } \\
\text { effect on proliferation }\end{array}$ & Valproic acid & $\begin{array}{l}\text { Valproic acid } \\
\text { inhibited } \\
\text { proliferation in } \\
\text { estrogen-sensitive } \\
\text { breast cancer cells }\end{array}$ & 3 \\
\hline
\end{tabular}


TABLE 2 | Continued

\begin{tabular}{|c|c|c|c|c|c|}
\hline Reference & Population & Study design & Intervention & Outcome & Score $/ 5$ \\
\hline lacopino et al., 2008 & $\begin{array}{l}\text { LNCaP; PC-3 } \\
\text { prostate cancer } \\
\text { cells }\end{array}$ & $\begin{array}{l}\text { In vitro study of drug } \\
\text { effect on proliferation }\end{array}$ & Valproic acid & $\begin{array}{l}\text { Valproic acid } \\
\text { inhibited } \\
\text { proliferation in both } \\
\text { cell lines to a } \\
\text { variable extent }\end{array}$ & 3 \\
\hline Jafary et al., 2014 & $\begin{array}{l}\text { MCF-7 breast } \\
\text { cancer cells }\end{array}$ & $\begin{array}{l}\text { In vitro study of drug } \\
\text { effect on proliferation }\end{array}$ & $\begin{array}{l}\text { Valproic } \\
\text { acid + nicotinamide }\end{array}$ & $\begin{array}{l}\text { Drug combination } \\
\text { inhibited } \\
\text { proliferation, } \\
\text { increased } \\
\text { apoptosis }\end{array}$ & 3 \\
\hline Jawed et al., 2007 & $\begin{array}{l}\text { MCF-7 breast } \\
\text { cancer cells }\end{array}$ & $\begin{array}{l}\text { In vitro study of drug } \\
\text { effect on proliferation }\end{array}$ & $\begin{array}{l}\text { Valproic } \\
\text { acid + melatonin }\end{array}$ & $\begin{array}{l}\text { Valproic acid } \\
\text { inhibited } \\
\text { proliferation in } \\
\text { presence/absence } \\
\text { of melatonin }\end{array}$ & 3 \\
\hline Jiang et al., 2014 & $\begin{array}{l}\text { PC3, DU145 } \\
\text { prostate cancer } \\
\text { cells }\end{array}$ & $\begin{array}{l}\text { In vitro study of drug } \\
\text { effect on invasion and } \\
\text { SMAD4 activity }\end{array}$ & Valproic acid & $\begin{array}{l}\text { Valproic acid } \\
\text { inhibited invasion } \\
\text { through AKT } \\
\text { pathway }\end{array}$ & 3 \\
\hline Li et al., 2012 & $\begin{array}{l}\text { MDA-MB-231 } \\
\text { breast cancer cells }\end{array}$ & $\begin{array}{l}\text { In vitro study of drug } \\
\text { effect on cell behaviors }\end{array}$ & Valproic acid & $\begin{array}{l}\text { Valproic acid } \\
\text { inhibited cell } \\
\text { migration but not } \\
\text { proliferation }\end{array}$ & 3 \\
\hline Li et al., 2014 & $\begin{array}{l}\text { MCF-7 and } \\
\text { MDA-MB-231 } \\
\text { breast cancer cells }\end{array}$ & $\begin{array}{l}\text { In vitro study of drug } \\
\text { effect on apoptosis }\end{array}$ & Lidocaine + cisplatin & $\begin{array}{l}\text { Lidocaine } \\
\text { enhanced } \\
\text { cisplatin-induced } \\
\text { apoptosis }\end{array}$ & 3 \\
\hline Olsen et al., 2004 & MCF-7 & $\begin{array}{l}\text { In vitro study of drug } \\
\text { effect on proliferation }\end{array}$ & $\begin{array}{l}\text { Phenytoin, } \\
\text { phenobarbital, valproic } \\
\text { acid, lamotrigine }\end{array}$ & $\begin{array}{l}\text { Phenytoin, } \\
\text { phenobarbital, and } \\
\text { valproic acid } \\
\text { inhibited } \\
\text { proliferation, } \\
\text { whereas } \\
\text { lamotrigine did not }\end{array}$ & 3 \\
\hline Papi et al., 2012 & $\begin{array}{l}\text { HT-29 and LoVo } \\
\text { colon carcinoma } \\
\text { cells }\end{array}$ & $\begin{array}{l}\text { In vitro study of drug } \\
\text { effect on proliferation, } \\
\text { invasion, and apoptosis }\end{array}$ & $\begin{array}{l}\text { Valproic acid + rexinoid } \\
\text { IIF }\end{array}$ & $\begin{array}{l}\text { Drug combination } \\
\text { inhibited cell growth } \\
\text { and invasion, } \\
\text { induced apoptosis }\end{array}$ & 3 \\
\hline Wedel et al., 2011 & $\begin{array}{l}\text { LNCaP; PC-3 } \\
\text { prostate cancer } \\
\text { cells }\end{array}$ & $\begin{array}{l}\text { In vitro study of drug } \\
\text { effect on cell behavior }\end{array}$ & $\begin{array}{l}\text { Valproic acid + mTOR } \\
\text { inhibitor RAD001 }\end{array}$ & $\begin{array}{l}\text { Valproic acid and } \\
\text { RAD001 reduced } \\
\text { cell adhesion and } \\
\text { migration }\end{array}$ & 3 \\
\hline Yoon et al., 2011 & $\begin{array}{l}\text { MCF10A, } \\
\text { MCF10A-Bc12, } \\
\text { MDA-MB-436 } \\
\text { breast epithelial, } \\
\text { and cancer cells }\end{array}$ & $\begin{array}{l}\text { In vitro study of drug } \\
\text { effect on cell behavior }\end{array}$ & Tetracaine, lidocaine & $\begin{array}{l}\text { Tetracaine and } \\
\text { lidocaine inhibit } \\
\text { microtentacle } \\
\text { attachment, } \\
\text { microfilament } \\
\text { organization, and } \\
\text { cell adhesion }\end{array}$ & 3 \\
\hline Zhang et al., 2011 & $\begin{array}{l}\text { RM-1 prostate } \\
\text { cancer cells }\end{array}$ & $\begin{array}{l}\text { In vitro study of drug } \\
\text { effect on } \\
\text { E-cadherin-mediated } \\
\text { cell migration }\end{array}$ & Valproic acid & $\begin{array}{l}\text { Valproic acid } \\
\text { promoted } \\
\text { E-cadherin } \\
\text { expression and } \\
\text { inhibited cell } \\
\text { migration. }\end{array}$ & 3 \\
\hline Zhang et al., 2012 & $\begin{array}{l}\text { MDA-MB-231 } \\
\text { breast cancer cells }\end{array}$ & $\begin{array}{l}\text { In vitro study of drug } \\
\text { effect on cell behavior }\end{array}$ & Valproic acid & $\begin{array}{l}\text { Valproic acid } \\
\text { inhibited cell } \\
\text { migration with } \\
\text { clinically relevant } \\
\text { doses }\end{array}$ & 3 \\
\hline
\end{tabular}




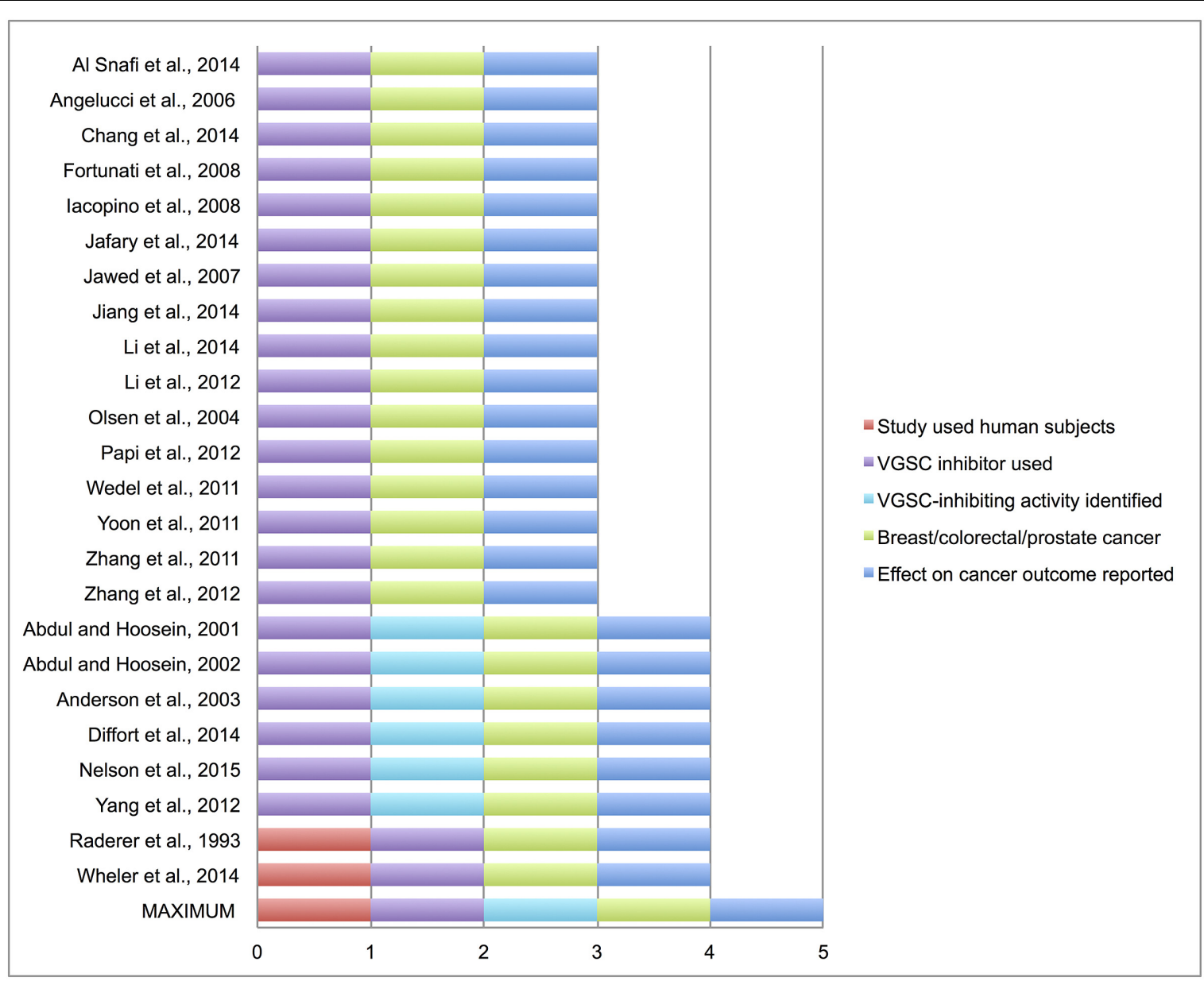

FIGURE 2 | Scoring of included studies. Study quality and evidence was quantified in the included studies (2 clinical and 22 preclinical) according to the modified standardized pre-piloted criteria assessment tool in Supplementary Table S3. Maximum score $=5$, minimum score for inclusion in systematic review $=3$.

phenytoin inhibited $\mathrm{Na}^{+}$current, migration and invasion of metastatic MDA-MB-231 breast cancer cells at clinically relevant doses, although it had no effect on cell proliferation. Importantly, phenytoin had no effect on proliferation, migration or invasion of weakly metastatic MCF-7 cells, which do not express $\mathrm{Na}^{+}$currents, suggesting that the effect of phenytoin is VGSC-dependent (Yang et al., 2012). All four studies suggest that further in vivo studies are warranted to explore the effect of VGSC-inhibiting drugs on cancer progression/metastasis.

There were two recent in vivo preclinical studies testing the effect of VGSC-inhibiting drugs on breast cancer metastasis in mice, which both scored 4 out of 5 . In Nelson et al. (2015), we showed that phenytoin slowed tumor growth, local invasion and metastasis in an orthotopic mouse breast cancer model. In addition, Driffort et al. (2014) showed that ranolazine reduced lung colonization in an experimental metastasis mouse model of breast cancer. In the same study, ranolazine was also found to inhibit $\mathrm{Na}^{+}$current, invasion and extracellular matrix degradation in vitro. Importantly, the effect of ranolazine on metastasis was equivalent to that of $\mathrm{Na}_{\mathrm{v}} 1.5$ down-regulation with
shRNA, suggesting that the metastasis-inhibiting effect of this drug is VGSC-dependent.

The remaining 17 studies scored 3 of 5 since they did not specifically look into the VGSC-inhibiting activity of the interventions. The most commonly tested drug was sodium valproate (13 studies) and the most common cell line breast cancer (11 studies). Not all drugs in these studies were tested at clinically relevant dosages, thus making the interpretation of some results and their clinical relevance challenging. For example, one study treated breast cancer cells with lidocaine in the range $0.01-1 \mathrm{mM}$ (Li et al., 2014). However, lidocaine toxicity in humans has been reported at doses $\geq 0.04 \mathrm{mM}$ (Collinsworth et al., 1974). Another study treated a range of tumor cell lines with sodium valproate at concentrations up to 10 times higher than the therapeutic range of $50-125 \mu \mathrm{g} / \mathrm{ml}$, although growth inhibition was also observed at doses as low as $31 \mu \mathrm{g} / \mathrm{ml}$ for some, but not all cell lines tested (Al Snafi et al., 2014). Overall six studies reported pro-apoptotic effects, eight inhibition of cell proliferation, five inhibition of migration, and four inhibition of invasion. Four studies reported no effects on proliferation (Figures 3A-E). 


\section{A}

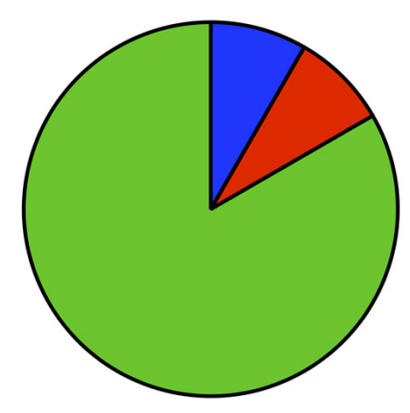

C

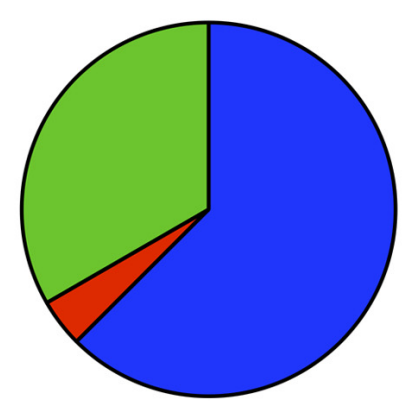

B

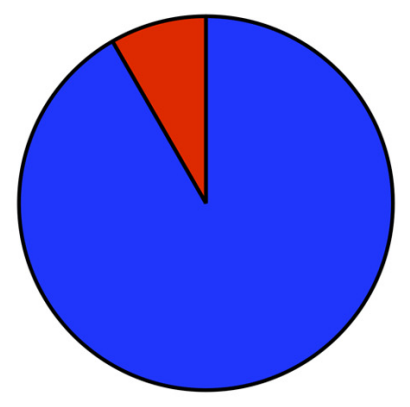

Monotherapy $(n=22)$

Combination $(n=2)$

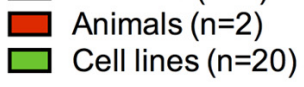

Cell lines $(n=20)$

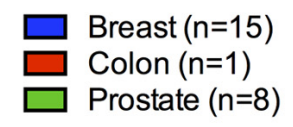

D

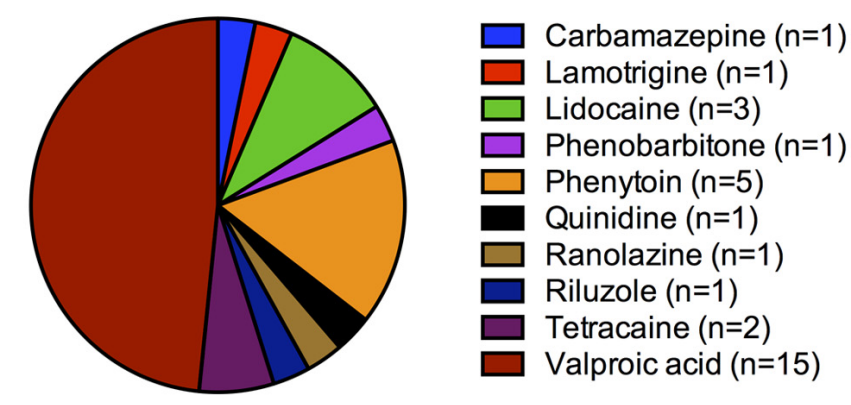

E

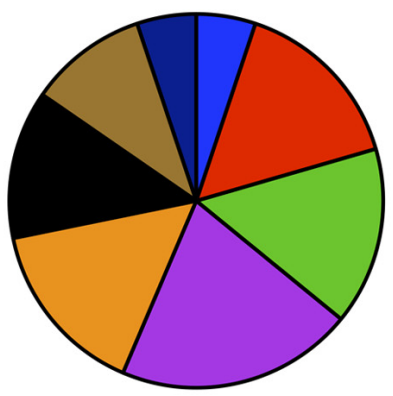

Side-effects \& patient survival $(n=2)$

VGSC inhibition $(n=6)$

HDAC inhibition $(n=6)$

Proliferation $(n=8)$

Apoptosis $(n=6)$

Migration $(n=5)$

Invasion $(n=4)$

Metastasis $(n=2)$

FIGURE 3 | Study distribution by cancer type, intervention and outcome measure. (A) Number of studies (\%) on humans, animals and cell lines. (B) Number of studies (\%) testing monotherapy vs. those testing multiple drugs in combination. (C) Number of studies (\%) on breast, colon and prostate cancer. (D) Studies (\%) divided by drug type. (E) Studies (\%) divided by outcome measure.

\section{DISCUSSION}

It is known that VGSCs are expressed in metastatic cells in various tumor types (Brackenbury, 2012). In addition, a number of studies using the (non-therapeutic) VGSC-blocking neurotoxin tetrodotoxin (Grimes et al., 1995; Laniado et al., 1997; Fraser et al., 1999, 2003, 2004, 2005; Roger et al., 2003; Brackenbury and Djamgoz, 2006), gene knockdown, e.g., siRNA (Brackenbury et al., 2007; House et al., 2010; Brisson et al., 2013), or over-expression approaches (Bennett et al., 2004; Chioni et al., 2009), have generated considerable mechanistic insight into the role of VGSCs in metastatic cancer cells, reviewed in detail elsewhere (Fraser et al., 2014a; Besson et al., 2015). The purpose of this study was to systematically investigate current clinical evidence that VGSC-inhibiting drugs slow cancer progression, e.g., by inhibiting tumor growth and/or metastasis. Our initial aim was to focus on human studies, however, we soon discovered a scarcity of human data in this field. We therefore expanded our 
search to preclinical studies. To our knowledge this is the first systematic review in this field of interest.

Twenty-four studies met the inclusion criteria and attained high quality scores $(\geq 3 / 5)$. Two were clinical drug trials, one of which was conducted in 1993 at a time when VGSC expression in cancer cells was not yet widely appreciated and therefore the VGSC-inhibiting mode of action of quinidine was not specifically investigated (Raderer et al., 1993). The second, more recent study investigated the HDAC inhibitory effects of sodium valproate as an adjuvant and its possible beneficial effect on survival (Wheler et al., 2014). Both studies included advanced disease, which would preclude the observation that VGSC inhibitors may elicit early antimetastatic effects by slowing invasion and/or preventing cancer progression. Indeed, most systemic anti-metastatic therapies capitalize on the understanding of late stages of the metastatic cascade, once tumor cells have already spread to secondary sites (Mina and Sledge, 2011), so a VGSC-targeting therapy may be highly novel. Although the lack of clinical data was disappointing, the systematic review of preclinical data allowed us to expose the broad range of VGSC inhibitors that have now been tested in various models as potential anti-cancer drugs. We discovered that a variety of modes of action were tested/postulated, and there was a notable lack of standardization in the outcome measures that were captured.

A key theme of the preclinical in vitro studies was that various VGSC inhibitors generally had an inhibitory effect on proliferation of cancer cells, and/or promoted apoptosis, either alone, or in combination with other chemotherapeutic agents. In the majority of cases, the VGSC-inhibiting mode of action of these drugs was not tested/identified. Indeed, the mode of action of the most commonly studied VGSCinhibiting drug, sodium valproate, was shown to be, at least partially, through HDAC inhibition in several studies (Angelucci et al., 2006; Zhang et al., 2011, 2012; Papi et al., 2012). Whilst this explanation is highly plausible, it cannot be excluded that valproate may also elicit its anti-tumor effects through additional mechanisms, including VGSC inhibition. In support of this notion, taking the general observation that different VGSC-inhibiting drugs, not all of which are HDAC inhibitors, have similar anticancer properties, their effects may be through another common mechanism, i.e., VGSC inhibition. A similar situation may occur for the $\mathrm{Ca}^{2+}$ channel blockers verapamil and diltiazem: these drugs elicit an anticancer effect by inhibiting $\mathrm{P}$ glycoprotein and multidrug resistance, but have also been shown to inhibit VGSCs in metastatic breast cancer cells (Roger et al., 2004). Further work is required to investigate these possibilities.

There were several key weaknesses with a number of the in vitro studies. Firstly, the methodology and outcome measures were not standardized across different studies, and interpretation of some measures was inconsistent, e.g., a relative reduction in cell number was variously interpreted as a reduction in proliferation, an increase in apoptosis, or an increase in cytotoxicity across different studies. Secondly, drug dosing was highly variable across different studies. Whilst some carefully reported the measured dose was within the therapeutic range for other indications (Yang et al., 2012; Nelson et al., 2015), others did not, and in several cases the dose was orders of magnitude above the therapeutic range (Al Snafi et al., 2014; Li et al., 2014), with the risk that the reported effects may be due to non-specific cytotoxicity. Clearly, further work is required to standardize dosing regimen across different in vitro models in order to unequivocally establish whether or not these drugs do indeed inhibit metastatic cell behaviors in different cancer cell types. Finally, the in vitro studies have generally focused on tumor cell lines in isolation without taking into consideration the possible effect of VGSC-inhibiting drugs on other cells in the heterogeneous tumor microenvironment, e.g., immune cells, or possible drug-drug interactions with concurrently administered chemotherapeutic agents (Vecht et al., 2003; Lo et al., 2012).

Despite the relatively large number of in vitro studies, our search revealed only two in vivo studies where VGSC inhibitors have been tested in mouse models (Driffort et al., 2014; Nelson et al., 2015). Both these studies employed xenografts of MDA-MB-231 breast cancer cells into immunocompromised mice, although one involved implantation at the orthotopic site and the other tail vein injection (spontaneous metastasis). Interestingly, both models showed a similar result, that the VGSC-inhibiting drugs tested inhibited metastatic dissemination of breast cancer cells. Similar to the in vitro studies, one weakness with these in vivo models is that they cannot consider the effects of the drugs on cell-cell interaction in a complex tumor microenvironment in immune-competent hosts (VargoGogola and Rosen, 2007). Nonetheless, it is worthy to note here that one study has shown that the VGSC-inhibiting neurotoxin tetrodotoxin, not licensed for clinical use, so excluded from our review, inhibits lung metastasis in a rat prostate cancer allograft model, an immunocompetent host (Yildirim et al., 2012).

It is important to note that several studies have shown that compounds not classically considered as VGSC-inhibiting therapeutic agents, e.g., the natural plant phenolic resveratrol and the omega-3 long chain polyunsaturated docosahexaenoic acid, reduce VGSC-dependent cancer cell migration and invasion (Isbilen et al., 2006; Fraser et al., 2014b; Wannous et al., 2015). In addition, recent evidence suggests that anesthetics that target VGSCs, e.g., ropivacaine, may also inhibit cancer cell invasion (Baptista-Hon et al., 2014). Furthermore, the voltagegated $\mathrm{Ca}^{2+}$ channel-targeting antiepileptic drug gabapentin, which may also inhibit VGSCs (Zhang et al., 2013), has recently been shown to inhibit invasion and metastasis of prostate cancer cells at high doses (Bugan et al., 2015). Finally, a recent study published in June 2015 (after the search period ended) has shown that lidocaine inhibits $\mathrm{Na}^{+}$current, extracellular signal-regulated kinase (ERK) phosphorylation and cellular invasion of SW620 colorectal cancer cells in vitro (House et al., 2015). Thus, VGSC inhibition via the use of various agents beyond the scope of this review may also have therapeutic value, and further work is required to establish this possibility in vivo. 
Based on this review, we make the following recommendations: Firstly, future clinical studies need to directly investigate the VGSC-inhibitory effects of relevant drugs using electrophysiological recording as an outcome measure. Second, clinically relevant in vivo models are needed to identify the most potent and safest VGSC-inhibiting drugs as anti-metastatic agents. Thirdly, methodology and outcome measures need to be standardized in order to be able to comparison of outcomes across tumor types and drugs. Finally, specific quality assessment tools are needed to evaluate in vitro studies of clinical interest.

\section{CONCLUSION}

There is only one registered clinical trial in cancer patients specifically exploring the anti-tumor effects of licensed VGSC blockers on survival. The study in question is a randomized open-label trial in India exploring the effect of lidocaine administration during surgery on disease-free survival of patients with operable breast cancer and will not complete until 2019 (ClinicalTrials.gov Identifier: NCT01916317). Given the large and growing body of preclinical evidence in favor of VGSC inhibitors as anti-tumor and anti-metastatic agents, clinical trials are urgently needed to explore this novel therapeutic angle in breast, colorectal, and prostate cancer patients. Novel agents that preferentially target the neonatal splice variant of VGSCs expressed in these adult cancers (Fraser et al., 2005; Baptista-Hon et al., 2014) should be developed and assessed. In addition, a number of the VGSC inhibitors investigated here are already licensed for non-cancer and cancer indications and could repurposed in phase 2 trials

\section{REFERENCES}

Abdul, M., and Hoosein, N. (2001). Inhibition by anticonvulsants of prostatespecific antigen and interleukin- 6 secretion by human prostate cancer cells. Anticancer. Res. 21, 2045-2048.

Abdul, M., and Hoosein, N. (2002). Voltage-gated sodium ion channels in prostate cancer: expression and activity. Anticancer. Res. 22, 1727-1730.

Al Snafi, A. E., Yaseen, N. Y., and Al Shatry, M. M. (2014). Anticancer effect of sodium valpoate. Int. J. Pharm. Technol. Res. 7, 291-297.

Anderson, J. D., Hansen, T. P., Lenkowski, P. W., Walls, A. M., Choudhury, I. M., Schenck, H. A., et al. (2003). Voltage-gated sodium channel blockers as cytostatic inhibitors of the androgen-independent prostate cancer cell line PC-3. Mol. Cancer Ther. 2, 1149-1154.

Angelucci, A., Valentini, A., Millimaggi, D., Gravina, G. L., Miano, R., Dolo, V., et al. (2006). Valproic acid induces apoptosis in prostate carcinoma cell lines by activation of multiple death pathways. Anticancer. Drugs 17, 1141-1150. doi: 10.1097/01.cad.0000236302.89843.fc

Baptista-Hon, D. T., Robertson, F. M., Robertson, G. B., Owen, S. J., Rogers, G. W., Lydon, E. L., et al. (2014). Potent inhibition by ropivacaine of metastatic colon cancer SW620 cell invasion and NaV1.5 channel function. Br. J. Anaesth. 113(Suppl. 1), i39-i48. doi: 10.1093/bja/aeu104

Bennett, E. S., Smith, B. A., and Harper, J. M. (2004). Voltage-gated $\mathrm{Na}^{+}$channels confer invasive properties on human prostate cancer cells. Pflugers. Arch. 447, 908-914. doi: 10.1007/s00424-003-1205-x

Besson, P., Driffort, V., Bon, E., Gradek, F., Chevalier, S., and Roger, S. (2015). How do voltage-gated sodium channels enhance migration and invasiveness in cancer cells? Biochim. Biophys. Acta 1848, 2493-2501. doi: 10.1016/j.bbamem.2015.04.013 specifically investigating their VGSC inhibitory and anti-cancer properties.

\section{AUTHOR CONTRIBUTIONS}

FM and IW had the original idea for this study. FM, CU, and WB conducted the analysis. FM, CU, and WB wrote the draft of the manuscript. IW and MB contributed to the development of the idea, and study design/interpretation. All authors approved the final submitted version of the manuscript.

\section{FUNDING}

This work was supported by the Medical Research Council [Fellowship G1000508] and the Wellcome Trust [ref: 097829] through the Centre for Chronic Diseases and Disorders (C2D2) at the University of York.

\section{ACKNOWLEDGMENT}

The authors wish to acknowledge the contribution of Rocio Rodriguez-Lopez to the development of the search strategy.

\section{SUPPLEMENTARY MATERIAL}

The Supplementary Material for this article can be found online at: http://journal.frontiersin.org/article/10.3389/fphar. 2015.00273

Black, J. A., and Waxman, S. G. (2013). Non-canonical roles of voltage-gated sodium channels. Neuron 80, 280-291. doi: 10.1016/j.neuron.2013.09.012

Brackenbury, W. J. (2012). Voltage-gated sodium channels and metastatic disease. Channels (Austin) 6, 352-361. doi: 10.4161/chan.21910

Brackenbury, W. J., Calhoun, J. D., Chen, C., Miyazaki, H., Nukina, N., Oyama, F., et al. (2010). Functional reciprocity between $\mathrm{Na}^{+}$channel Nav1.6 and $\beta 1$ subunits in the coordinated regulation of excitability and neurite outgrowth. Proc. Natl. Acad. Sci. U.S.A. 107, 2283-2288. doi: 10.1073/pnas.0909 434107

Brackenbury, W. J., Chioni, A. M., Diss, J. K., and Djamgoz, M. B. (2007). The neonatal splice variant of Nav1.5 potentiates in vitro metastatic behaviour of MDA-MB-231 human breast cancer cells. Breast Cancer Res. Treat. 101, 149-160. doi: 10.1007/s10549-006-9281-1

Brackenbury, W. J., Davis, T. H., Chen, C., Slat, E. A., Detrow, M. J., Dickendesher, T. L., et al. (2008a). Voltage-gated $\mathrm{Na}^{+}$channel $\beta 1$ subunitmediated neurite outgrowth requires fyn kinase and contributes to central nervous system development in vivo. J. Neurosci. 28, 3246-3256. doi: 10.1523/JNEUROSCI.5446-07.2008

Brackenbury, W. J., Djamgoz, M. B., and Isom, L. L. (2008b). An emerging role for voltage-gated $\mathrm{Na}^{+}$channels in cellular migration: regulation of central nervous system development and potentiation of invasive cancers. Neuroscientist 14, 571-583. doi: 10.1177/1073858408320293

Brackenbury, W. J., and Djamgoz, M. B. (2006). Activity-dependent regulation of voltage-gated $\mathrm{Na}^{+}$channel expression in Mat-LyLu rat prostate cancer cell line. J. Physiol. 573, 343-356. doi: 10.1113/jphysiol.2006.106906

Brackenbury, W. J., and Isom, L. L. (2008). Voltage-gated $\mathrm{Na}^{+}$channels: potential for beta subunits as therapeutic targets. Expert Opin. Ther. Targets 12, 1191-1203. doi: 10.1517/14728222.12.9.1191 
Brackenbury, W. J., and Isom, L. L. (2011). Na Channel beta Subunits: overachievers of the Ion Channel Family. Front Pharmacol 2:53. doi: 10.3389/fphar.2011.00053

Brackenbury, W. J., Yuan, Y., O'malley, H. A., Parent, J. M., and Isom, L. L. (2013). Abnormal neuronal patterning occurs during early postnatal brain development of Scn1b-null mice and precedes hyperexcitability. Proc. Natl. Acad. Sci. U.S.A. 110, 1089-1094. doi: 10.1073/pnas.1208767110

Brisson, L., Driffort, V., Benoist, L., Poet, M., Counillon, L., Antelmi, E., et al. (2013). NaV1.5 $\mathrm{Na}(+)$ channels allosterically regulate the NHE-1 exchanger and promote the activity of breast cancer cell invadopodia. J. Cell Sci. 126, 4835-4842. doi: 10.1242/jcs.123901

Bugan, I., Karagoz, Z., Altun, S., and Djamgoz, M. B. (2015). Gabapentin, an analgesic used against cancer-associated neuropathic pain: effects on prostate cancer progression in an in vivo rat model. Basic Clin. Pharmacol. Toxicol. doi: 10.1111/bcpt.12484 [Epub ahead of print].

Catterall, W. A. (2000). From ionic currents to molecular mechanisms: the structure and function of voltage-gated sodium channels. Neuron 26, 13-25. doi: 10.1016/S0896-6273(00)81133-2

Chang, Y. C., Liu, C. L., Chen, M. J., Hsu, Y. W., Chen, S. N., Lin, C. H., et al. (2014). Local anesthetics induce apoptosis in human breast tumor cells. Anesth. Analg. 118, 116-124. doi: 10.1213/ANE.0b013e3182a94479

Chioni, A. M., Brackenbury, W. J., Calhoun, J. D., Isom, L. L., and Djamgoz, M. B. (2009). A novel adhesion molecule in human breast cancer cells: voltagegated $\mathrm{Na}^{+}$channel betal subunit. Int. J. Biochem. Cell Biol. 41, 1216-1227. doi: 10.1016/j.biocel.2008.11.001

Collinsworth, K. A., Kalman, S. M., and Harrison, D. C. (1974). The clinical pharmacology of lidocaine as an antiarrhythymic drug. Circulation 50, 12171230. doi: 10.1161/01.CIR.50.6.1217

Driffort, V., Gillet, L., Bon, E., Marionneau-Lambot, S., Oullier, T., Joulin, V., et al. (2014). Ranolazine inhibits NaV1.5-mediated breast cancer cell invasiveness and lung colonization. Mol. Cancer 13:264. doi: 10.1186/1476-4598-13-264

Fairhurst, C., Watt, I., Martin, F., Bland, M., and Brackenbury, W. J. (2014). Exposure to sodium channel-inhibiting drugs and cancer survival: protocol for a cohort study using the Q Research primary care database. BMJ Open 4:e006604. doi: 10.1136/bmjopen-2014-006604

Fortunati, N., Bertino, S., Costantino, L., Bosco, O., Vercellinatto, I., Catalano, M. G., et al. (2008). Valproic acid is a selective antiproliferative agent in estrogen-sensitive breast cancer cells. Cancer Lett. 259, 156-164. doi: 10.1016/j.canlet.2007.10.006

Fraser, S. P., Ding, Y., Liu, A., Foster, C. S., and Djamgoz, M. B. (1999). Tetrodotoxin suppresses morphological enhancement of the metastatic MATLyLu rat prostate cancer cell line. Cell Tissue Res. 295, 505-512. doi: $10.1007 / \mathrm{s} 004410051256$

Fraser, S. P., Diss, J. K., Chioni, A. M., Mycielska, M. E., Pan, H., Yamaci, R. F., et al. (2005). Voltage-gated sodium channel expression and potentiation of human breast cancer metastasis. Clin. Cancer Res. 11, 5381-5389. doi: 10.1158/10780432.CCR-05-0327

Fraser, S. P., Diss, J. K., Lloyd, L. J., Pani, F., Chioni, A. M., George, A. J., et al. (2004). T-lymphocyte invasiveness: control by voltage-gated $\mathrm{Na}+$ channel activity. FEBS Lett. 569, 191-194. doi: 10.1016/j.febslet.2004. 05.063

Fraser, S. P., Ozerlat-Gunduz, I., Brackenbury, W. J., Fitzgerald, E. M., Campbell, T. M., Coombes, R. C., et al. (2014a). Regulation of voltagegated sodium channel expression in cancer: hormones, growth factors and auto-regulation. Philos. Trans. R. Soc. Lond. B Biol. Sci. 369:20130105. doi: 10.1098/rstb.2013.0105

Fraser, S. P., Peters, A., Fleming-Jones, S., Mukhey, D., and Djamgoz, M. B. (2014b). Resveratrol: inhibitory effects on metastatic cell behaviors and voltagegated $\mathrm{Na}(+)$ channel activity in rat prostate cancer in vitro. Nutr. Cancer 66, 1047-1058. doi: 10.1080/01635581.2014.939291

Fraser, S. P., Salvador, V., Manning, E. A., Mizal, J., Altun, S., Raza, M., et al. (2003). Contribution of functional voltage-gated $\mathrm{Na}^{+}$channel expression to cell behaviors involved in the metastatic cascade in rat prostate cancer: I. lateral motility. J. Cell Physiol. 195, 479-487. doi: 10.1002/jcp.10312

Grimes, J. A., Fraser, S. P., Stephens, G. J., Downing, J. E., Laniado, M. E., Foster, C. S., et al. (1995). Differential expression of voltage-activated $\mathrm{Na}+$ currents in two prostatic tumour cell lines: contribution to invasiveness in vitro. FEBS Lett. 369, 290-294. doi: 10.1016/0014-5793(95)00772-2
House, C. D., Vaske, C. J., Schwartz, A., Obias, V., Frank, B., Luu, T., et al. (2010). Voltage-gated $\mathrm{Na}^{+}$channel SCN5A is a key regulator of a gene transcriptional network that controls colon cancer invasion. Cancer Res. 70, 6957-6967. doi: 10.1158/0008-5472.CAN-10-1169

House, C. D., Wang, B. D., Ceniccola, K., Williams, R., Simaan, M., Olender, J., et al. (2015). Voltage-gated $\mathrm{Na}^{+}$channel activity increases colon cancer transcriptional activity and invasion via persistent MAPK signaling. Sci. Rep. 5:11541. doi: 10.1038/srep11541

Iacopino, F., Urbano, R., Graziani, G., Muzi, A., Navarra, P., and Sica, G. (2008). Valproic acid activity in androgen-sensitive and -insensitive human prostate cancer cells. Int. J. Oncol. 32, 1293-1303.

Isbilen, B., Fraser, S. P., and Djamgoz, M. B. (2006). Docosahexaenoic acid (omega3) blocks voltage-gated sodium channel activity and migration of MDA-MB231 human breast cancer cells. Int. J. Biochem. Cell Biol. 38, 2173-2182. doi 10.1016/j.biocel.2006.06.014

Jafary, H., Ahmadian, S., and Soleimani, M. (2014). The enhanced apoptosis and antiproliferative response to combined treatment with valproate and nicotinamide in MCF-7 breast cancer cells. Tumour. Biol. 35, 2701-2710. doi: 10.1007/s13277-013-1356-0

Jawed, S., Kim, B., Ottenhof, T., Brown, G. M., Werstiuk, E. S., and Niles, L. P. (2007). Human melatonin MT1 receptor induction by valproic acid and its effects in combination with melatonin on MCF-7 breast cancer cell proliferation. Eur. J. Pharmacol. 560, 17-22. doi: 10.1016/j.ejphar.2007.01.022

Jemal, A., Bray, F., Center, M. M., Ferlay, J., Ward, E., and Forman, D. (2011), Global cancer statistics. CA Cancer J. Clin. 61, 69-90. doi: 10.3322/caac.20107

Jiang, W., Zheng, Y., Huang, Z., Wang, M., Zhang, Y., Wang, Z., et al. (2014). Role of SMAD4 in the mechanism of valproic acid's inhibitory effect on prostate cancer cell invasiveness. Int. Urol. Nephrol. 46, 941-946. doi: 10.1007/s11255013-0609-6

Laniado, M. E., Lalani, E. N., Fraser, S. P., Grimes, J. A., Bhangal, G., Djamgoz, M. B., et al. (1997). Expression and functional analysis of voltage-activated $\mathrm{Na}^{+}$ channels in human prostate cancer cell lines and their contribution to invasion in vitro. Am. J. Pathol. 150, 1213-1221.

Li, G. F., Qian, T. L., Li, G. S., Yang, C. X., Qin, M., Huang, J., et al. (2012). Sodium valproate inhibits MDA-MB-231 breast cancer cell migration by upregulating NM23H1 expression. Genet. Mol. Res. 11, 77-86. doi: 10.4238/2012.January.13.1

Li, K., Yang, J., and Han, X. (2014). Lidocaine sensitizes the cytotoxicity of cisplatin in breast cancer cells via up-regulation of RARbeta2 and RASSF1A demethylation. Int. J. Mol. Sci. 15, 23519-23536. doi: 10.3390/ijms1512 23519

Lo, W. L., Donermeyer, D. L., and Allen, P. M. (2012). A voltage-gated sodium channel is essential for the positive selection of CD4(+) T cells. Nat. Immunol. 13, 880-887. doi: 10.1038/ni.2379

Mantegazza, M., Curia, G., Biagini, G., Ragsdale, D. S., and Avoli, M. (2010). Voltage-gated sodium channels as therapeutic targets in epilepsy and other neurological disorders. Lancet Neurol. 9, 413-424. doi: 10.1016/S14744422(10)70059-4

Mina, L. A., and Sledge, G. W. Jr. (2011). Rethinking the metastatic cascade as a therapeutic target. Nat. Rev. Clin. Oncol. 8, 325-332. doi: 10.1038/nrclinonc.2011.59

Moher, D., Liberati, A., Tetzlaff, J., Altman, D. G., and Group, P. (2009). Preferred reporting items for systematic reviews and meta-analyses: the PRISMA statement. BMJ 339:b2535. doi: 10.1136/bmj.b2535

Nelson, M., Yang, M., Dowle, A. A., Thomas, J. R., and Brackenbury, W. J. (2015). The sodium channel-blocking antiepileptic drug phenytoin inhibits breast tumour growth and metastasis. Mol. Cancer 14:13. doi: 10.1186/s12943014-0277-x

NHLBI (2014). Quality Assessment Tool for Observational Cohort and CrossSectional Studies [Internet]. [Bethesda (MD)]: National Institutes of Health (US), National Heart, Lung and Blood Institute (NHLBI). Available: http://www.nhlbi. nih.gov/health-pro/guidelines/in-develop/cardiovascular-risk-reduction/ tools/cohort [accessed July 02, 2015].

Olsen, C. M., Meussen-Elholm, E. T., Roste, L. S., and Tauboll, E. (2004). Antiepileptic drugs inhibit cell growth in the human breast cancer cell line MCF7. Mol. Cell. Endocrinol. 213, 173-179. doi: 10.1016/j.mce.2003.10.032

Papi, A., Ferreri, A. M., Guerra, F., and Orlandi, M. (2012). Anti-invasive effects and proapoptotic activity induction by the rexinoid IIF and valproic 
acid in combination on colon cancer cell lines. Anticancer. Res. 32, 2855-2862.

Raderer, M., Depisch, D., Haider, K., Kwasny, W., Djavanmard, M., and Scheithauer, W. (1993). A Phase 1/ll study of quinidine, a potential multidrug resistance-reversing agent, in combination with pirarubicin in patients with advanced refractory breast cancer. Onkologie 16, 450-453. doi: $10.1159 / 000218305$

Roger, S., Besson, P., and Le Guennec, J. Y. (2003). Involvement of a novel fast inward sodium current in the invasion capacity of a breast cancer cell line. Biochim. Biophys. Acta 1616, 107-111. doi: 10.1016/j.bbamem.2003.07.001

Roger, S., Guennec, J. Y., and Besson, P. (2004). Particular sensitivity to calcium channel blockers of the fast inward voltage-dependent sodium current involved in the invasive properties of a metastastic breast cancer cell line. $\mathrm{Br} . \mathrm{J}$. Pharmacol. 141, 610-615. doi: 10.1038/sj.bjp.0705649

Roger, S., Potier, M., Vandier, C., Besson, P., and Le Guennec, J. Y. (2006). Voltagegated sodium channels: new targets in cancer therapy? Curr. Pharm. Des. 12, 3681-3695. doi: 10.2174/138161206778522047

Vargo-Gogola, T., and Rosen, J. M. (2007). Modelling breast cancer: one size does not fit all. Nat. Rev. Cancer 7, 659-672. doi: 10.1038/nrc2193

Vecht, C. J., Wagner, G. L., and Wilms, E. B. (2003). Interactions between antiepileptic and chemotherapeutic drugs. Lancet Neurol. 2, 404-409. doi: 10.1016/S1474-4422(03)00435-6

Wannous, R., Bon, E., Gillet, L., Chamouton, J., Weber, G., Brisson, L., et al. (2015). Suppression of PPARbeta, and DHA treatment, inhibit NaV1.5 and NHE-1 pro-invasive activities. Pflugers Arch. 467, 1249-1259. doi: 10.1007/s00424-0141573-4

Wedel, S., Hudak, L., Seibel, J. M., Makarevic, J., Juengel, E., Tsaur, I., et al. (2011). Impact of combined HDAC and mTOR inhibition on adhesion, migration and invasion of prostate cancer cells. Clin. Exp. Metastasis 28, 479-491. doi: 10.1007/s10585-011-9386-8

Wheler, J. J., Janku, F., Falchook, G. S., Jackson, T. L., Fu, S., Naing, A., et al. (2014). Phase I study of anti-VEGF monoclonal antibody bevacizumab and histone deacetylase inhibitor valproic acid in patients with advanced cancers. Cancer Chemother. Pharmacol. 73, 495-501. doi: 10.1007/s00280-014-2384-1
Yang, M., Kozminski, D. J., Wold, L. A., Modak, R., Calhoun, J. D., Isom, L. L., et al. (2012). Therapeutic potential for phenytoin: targeting $\mathrm{Na}(\mathrm{v}) 1.5$ sodium channels to reduce migration and invasion in metastatic breast cancer. Breast Cancer Res. Treat. 134, 603-615. doi: 10.1007/s10549-012-2102-9

Yildirim, S., Altun, S., Gumushan, H., Patel, A., and Djamgoz, M. B. (2012). Voltage-gated sodium channel activity promotes prostate cancer metastasis in vivo. Cancer Lett. 323, 58-61. doi: 10.1016/j.canlet.2012.03.036

Yoon, J. R., Whipple, R. A., Balzer, E. M., Cho, E. H., Matrone, M. A., Peckham, M., et al. (2011). Local anesthetics inhibit kinesin motility and microtentacle protrusions in human epithelial and breast tumor cells. Breast Cancer Res. Treat. 129, 691-701. doi: 10.1007/s10549-010-1239-7

Zhang, J. L., Yang, J. P., Zhang, J. R., Li, R. Q., Wang, J., Jan, J. J., et al. (2013). Gabapentin reduces allodynia and hyperalgesia in painful diabetic neuropathy rats by decreasing expression level of Nav1.7 and p-ERK1/2 in DRG neurons. Brain Res. 1493, 13-18. doi: 10.1016/j.brainres.2012.11.032

Zhang, L., Wang, G., Wang, L., Song, C., Leng, Y., Wang, X., et al. (2012). VPA inhibits breast cancer cell migration by specifically targeting HDAC2 and down-regulating Survivin. Mol. Cell. Biochem. 361, 39-45. doi: 10.1007/s11010011-1085-x

Zhang, L., Wang, G., Wang, L., Song, C., Wang, X., and Kang, J. (2011). Valproic acid inhibits prostate cancer cell migration by up-regulating E-cadherin expression. Pharmazie 66, 614-618.

Conflict of Interest Statement: The authors declare that the research was conducted in the absence of any commercial or financial relationships that could be construed as a potential conflict of interest.

Copyright (c) 2015 Martin, Ufodiama, Watt, Bland and Brackenbury. This is an open-access article distributed under the terms of the Creative Commons Attribution License (CC BY). The use, distribution or reproduction in other forums is permitted, provided the original author(s) or licensor are credited and that the original publication in this journal is cited, in accordance with accepted academic practice. No use, distribution or reproduction is permitted which does not comply with these terms. 